\title{
Effect of Moringa oleifera leaf on the efficiency to increase protein supply to ruminants
}

\author{
RA Karim¹, MR Amin²*, M Moniruzzaman², MB Sarker², AKMA Kabir² \\ ${ }^{1}$ Goat and Sheep Division, Bangladesh Livestock Research Institute, Saver, Dhaka 1213; ${ }^{2}$ Department of \\ Animal Science, Bangladesh Agricultural University, Mymensingh 2202, Bangladesh
}

\begin{abstract}
Moringa oleifera leaf was investigated for nutritional quality, presence of tannins and its activity using polyethyelene glycol (PEG) and in vitro study of protein degradation in the rumen. The antibiotic growth promoter (AGP), Monensin was used as an external control to compare with the degradation of Moringa leaves. The different forms of tannin content in Moringa leaves were very negligible. Total phenol, total tannin, condensed tannin and hydrolysable tannin contents of Moringa leaves were 3.92 \pm 0.42 , $1.19 \pm 0.14,0.57 \pm 0.06$ and $0.07 \pm 0.02 \mathrm{mg} / \mathrm{g}$, respectively. The in vitro gas production, organic matter digestibility (OMD\%) and metabolizable energy (ME) content of Moringa leaves were $54.39 \mathrm{ml}, 77.44 \%$ and $11.14 \mathrm{MJ} / \mathrm{kgDM}$, respectively. There were no significant differences in gas production, in vitro OMD\% and ME content in the presence of tannin binding agent PEG. These results indicated that the different forms of tannin present in Moringa leaves are not active tannins, therefore, feeding Moringa leaves are safe for the ruminant animals. The kinetic study of in vitro gas production with Moringa leaves and Monensin showed almost similar results and there was no significant difference among them but higher values were found in the control indicated that Moringa leaves have the ability to inhibit the breakdown of protein in the rumen as of Monensin. On the contrary, soluble protein concentration was increased $182 \%$ with the addition of Moringa leaves compared to control and the values were almost close $(213 \%)$ with Monensin during the $12 \mathrm{~h}$ incubation period. The pellet protein concentration was also increased $(119 \%)$ with Moringa leaves and Monensin (115\%) compared to control although there was no significant difference between them. Therefore, it can be concluded from the present findings that feeding Moringa leaves appeared to be an alternative source of protein and are safe for ruminant animals. Moringa leaves have been shown to alter favorably ruminal protein fermentation characteristics thus spare protein by a decreased breakdown/deamination of protein/amino acids that functions as of Monensin.
\end{abstract}

Key words: Moringa oleifera, tannin, monensin, in vitro study, digestibility, protein degradation, ruminant.

Bangladesh Animal Husbandry Association. All rights reserved.

Bang. J. Anim. Sci. 2015. 44 (1): 46-51

\section{Introduction}

The efficient utilization of dietary protein is a key issue of ruminant nutrition in intensive production systems. In the rumen, $70-80 \%$ of the protein is degraded via peptides and amino acids to ammonia and fatty acids (Barry and McNabb 1999). To sustain productivity, especially high yielding dairy cows need further amount of bypass protein that can be hydrolysed and absorbed post-ruminally (Santos et al. 1998). Thus, the proportion of by-pass protein constitutes one of the major factors of feed nitrogen value (Michelet-Doreau and Ould-Bah 1992).

*Corresponding Author: aminmr64@yahoo.com
One of the impacts of ionophores, such as monensin, lasalocid, laidlomycin, salinomycin and narasin, common antibiotic growth promoter (AGP) in ruminant rations, has been shown to alter favorably ruminal fermentation characteristics and metabolism in the rumen (Newbold et al. 1988; Russell et al. 1991), thus spare protein by a decreased de-amination of amino acids (Yang and Russel 1993). AGP used for milk and meat production have already been criticized and banned by the European Union from 2006, as they may leave harmful residues in the food chain and promote the spreading of resistance genes (Hoffmann et al. 2003). Livestock 
producers need alternative means of obtaining similar production benefits to maintain profitability and competitiveness against overseas producers, including the US, where such restrictions do not exist.

The Moringa oleifera is a multipurpose fastgrowing tree and is high in protein and rich in vitamins and minerals can be a good source as an alternative feed (Amin 2011) for increasing milk and meat production of ruminants. There is lack of information of Moringa leaves on the antinutritional content and its quality, degradation pattern specially protein degradation in the rumen and the availability of protein postruminally. Investigations are needed to be directed in these areas, which are likely to have immense nutritional and ecological significance, and feeding strategies need to be designed to explore the benefits. As far as we are aware, there is no information on the tannin content of Moringa leaves from Bangladeshi origin and their effects on the fermentation pattern in the rumen. Therefore, the present experiment was conducted to investigate nutritive value, presence of tannin and its activity using polyethylene glycol (PEG), rumen fermentation patterns and kinetic study particularly the nature of protein degradation in the rumen with Moringa leaves.

\section{Materials and Methods}

The study was conducted in the Department of Animal Science, Bangladesh Agricultural University, Mymensingh. Freshly flushed representative samples of Moringa leaves were collected from different areas of Bangladesh Agricultural University campus area of Mymensingh district, Bangladesh, dried in the oven at $30^{\circ} \mathrm{C}$ and kept in polythene bag for further analysis. Samples were ground in grinding machine (CYCLOTEC 1993 Sample mill Tecator, Sweden) at $0.5 \mathrm{~mm}$ sieve for tannin analysis and in vitro study. The ground samples were bottled covered with aluminum foil and kept in desiccators.

Total phenols was estimated by Folion Ciocalteu reagent method and total tannin was determined by subtracting the values of polyvinyl pyrrolidone (PVPP) bind tannins from total phenols. Condensed tannin was determined by oxidation in butanol- $\mathrm{HCl}$ reagent in presence of iron and gallotannins was determined by hydrolysis of gallotannins to gallic acid with rhodanine. Both the total phenols and total tannins were expressed as tannic acid equivalent. The condensed tannin and gallotannin (hydrolizable tannins) were expressed as lecucyanidin equivalent and gallic acid equivalent, respectively. The above analyses were conducted according to laboratory manual of quantification of tannins in tree foliage (Makkar 2000).

Series of experiments were carried out to study the effect of tannins on rumen fermentation using hay and hay-starch as standard. In this study, sun dried leaf samples of Moringa leaves was used. The method, in principle, was based on the in vitro gas production technique described by Menke et al. (1979) and Menke and Steingass (1988).

The organic matter digestibility (OMD \%) and metabolizable energy (ME) content (MJ/kg DM) were calculated from the gas volume (Gv) and crude protein value (CP \%) using the following equations (Menke and Steingass 1988).

$\% \mathrm{OMD}=14.88+0.889 \times \mathrm{Gv}+0.45 \times \% \mathrm{CP}$ and

$\mathrm{ME}=2.20+0.136 \times \mathrm{GV}+0.057 \times \% \mathrm{CP}$

For the determination of soluble and pellet protein, in vitro gas production technique was carried out. The substrate is composed of straw (6 $\mathrm{mg} / \mathrm{ml}$ ), soybean meal $(5 \mathrm{mg} / \mathrm{ml}$ ) and $\mathrm{M}$. oleifera ground leaves $(9 \mathrm{mg} / \mathrm{ml}$ ). Monensin ( 3 $\mu \mathrm{M})$ served as an external control. The samples (360 mg) were taken into the glass bottles and $40 \mathrm{ml}$ of rumen liquor was taken in each bottle for incubation at $39^{\circ} \mathrm{C}$. One $\mathrm{ml}$ sample was collected for the analyses of protein degradation kinetics at 1, 3, 6, 9 and $12 \mathrm{~h}$ intervals. The samples were centrifuged at $15,000 \mathrm{rpm}$ for $15 \mathrm{~min}$ at $4{ }^{\circ} \mathrm{C}$ for the separation of the soluble and pellet fractions. Both soluble and pellet fractions were boiled at $100^{\circ} \mathrm{C}$ for 5 minutes, centrifuged again at 15000 rpm for 15 minutes, collected supernatents and pellets to determine soluble and pellet protein according to method of Lowry et al. (1951). Statistical analysis of the data obtained from the study was analyzed to interpret in a 
comprehensive way. The collected data was analyzed with the help of SPSS and SAS computer package.

\section{Results and Discussions}

The total phenol (TP), total tannin (TT), condensed tannin (CT) and hydrolysable tannin (HT) contents of Moringa leaves are presented in Table 1. The different forms of tannin in Moringa leaves were found to be negligible. Tannin levels in plants are known to vary greatly between species, within species, stage of development, between various tissues of the same plant, from location to location and from year to year (Mehansho et al. 1987). A study done by Gupta et al. (1989) showed that the unextracted leaves of $\mathrm{M}$. oleifera contained $2.7 \% \mathrm{TP}$, negligible amounts of TT (1.4\%) and CT was not detectable. In the extracted leaves, no $\pi$ was detected and the content of TP was very low (1.6 $\%)$. At this concentration, these simple phenols do not produce any adverse effects when eaten by the animals. In the present research, TP and TT concentration were found lower than the values of Gupta et al. (1989).

Table 1. Different forms of tannin content of Moringa oleifera leaves

\begin{tabular}{lc}
\hline Different form of tannins & Tannin contents $(\mathrm{mg} / \mathrm{g})$ \\
\hline Total phenolics (TP) & $3.92 \pm 0.42$ \\
Total tannin (TT) & $1.19 \pm 0.14$ \\
Condensed tannin (CT) & $0.57 \pm 0.06$ \\
Hidrolizable tannin (HT) & $0.07 \pm 0.02$ \\
\hline
\end{tabular}

The amount of gas produced up to $24 \mathrm{~h}$ of incubation of Moringa leaves in vitro with and without PEG is presented in Table 2. Addition of PEG tended to increase gas production by $2.5 \%$ and the value was not significant. Usually, the increase in gas production by the addition of PEG was achieved by inhibiting the action of tannin on digestion in the rumen and resulted in increased microbial fermentation (Makkar and Becker 1996) but in the present experiment, there was slight increase in gas production but not significant. Higher the biological activity of tannins on rumen microbes, lower is the gas production (Makkar et al. 1995, Mangan 1988). So it is suggested from the gas production values that the tannins present in Moringa leaves are not active tannin and the addition of tannin-binding agent PEG can increase gas production as well as the utilization of tannin-rich foliages.

The amount of organic matter digestibility (OMD\%) and metabolizable energy (ME) content with and without PEG are shown in Table 2. There were no significant differences between the OMD\% and ME content of Moringa leaves with and without PEG, although, the addition of PEG resulted in increase of OMD\% and ME content by only $2 \%$ and $7.5 \%$, respectively. The nutritive value of organic matter fed to ruminants is influenced substantially by the protein content of the foliages and by the extent to which it is degraded in the rumen. Formation of PEG-tannin complexes could effect on in vitro OMD\% of tanniniferous foliages by reducing microbial effect on organic matter and its digestibility (Palmer and Jones, 1999). In the present experiment, the OMD\% and the ME content were not increased significantly. The present study further validated the finding that the addition of PEG if added to inactive tannins may not increase OMD\% and ME content if the tannin concentration is low or not active. There is an inverse relationship between the contents of tannins, gas production and metabolizable energy content (Waghorn and Stafford 1993). It was revealed that low concentration of tannins has led to high gas volume and consequently ME content in foliages (Makkar et al. 1995). The result of the present study fully agreed with the finding of Makkar et al. (1995) and Kabir et al. (2004).

Table 2. Effect of PEG on in vitro gas production, organic matter digestibility (OMD\%) and ME content of Moringa oleifera leaves.

\begin{tabular}{lcccccc}
\hline Samples & IGP (ml) & $\begin{array}{c}\text { Increase } \\
(\%)\end{array}$ & $\begin{array}{c}\text { OMD } \\
(\%)\end{array}$ & $\begin{array}{c}\text { Increase ME (MJ/ } \\
(\%)\end{array}$ & $\begin{array}{l}\text { kg DM) } \\
\text { Incease } \\
(\%)\end{array}$ \\
\hline Leaf (-PEG) & 54.39 & $2.5 \%$ & 77.44 & $2 \%$ & 11.14 & $7.5 \%$ \\
Leaf (+PEG) & 55.78 & & 78.98 & & 12.25 & \\
Sig. level & NS & & NS & & NS & \\
\hline
\end{tabular}

PGE, polyethyelene glycol; IGP, In vitro gas production

The amount of cumulative gas produced in Moringa leaves and Monensin as \% of control during $12 \mathrm{~h}$ of incubation is presented in Figure 1. The gas production in control was always higher than with Moringa leaves and Monensin. The in 
vitro gas production kinetics with Moringa leaves and Monensin showed almost similar trend but higher values were found in the control indicated that Moringa leaves have the ability to inhibit the breakdown of protein in the rumen as of Monensin.

\section{Gas production kinetics}

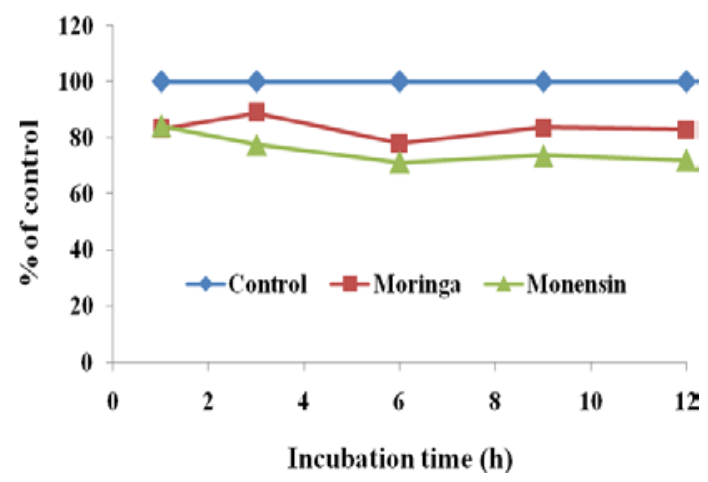

Figure 1. Cumulative in vitro gas production kinetics of Moringa leaves

The amount of soluble protein (SP) produced in Moringa leaves and Monensin as \% of control during $12 \mathrm{~h}$ of incubation is presented in Figure 2. The SP concentration with Monensin was always higher than Moringa leaves and control and the trend being almost similar between Moringa and Monensin during $12 \mathrm{~h}$ incubation. The SP concentration was increased $182 \%$ with the addition of Moringa leaves compared to control and the value was almost close $(213 \%)$ with Monensin during $12 \mathrm{~h}$ incubation indicated that Moringa leaf was able to increase soluble protein concentration in vitro in the rumen as of Monensin.

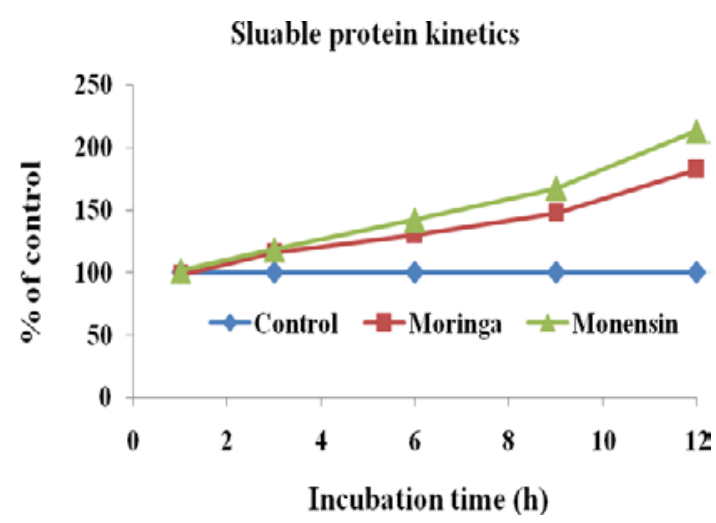

Figure 2. Cumulative soluble protein concentration kinetics of Moringa leaves
The amount of pellet protein (PP) concentration in Moringa leaves and Monensin as \% of control during $12 \mathrm{~h}$ incubation is presented in Figure 3 . The PP concentration was always higher in Moringa leaves than Monensin and control and the trend being almost similar between Moringa and Monensin during $12 \mathrm{~h}$ of incubation. The PP concentration was increased $119 \%$ with the addition of Moringa leaves compared to control and the value was almost close $(115 \%)$ with Monensin during $12 \mathrm{~h}$ incubation indicated that Moringa leaf was able to increase PP concentration in vitro in the rumen as of Monensin.

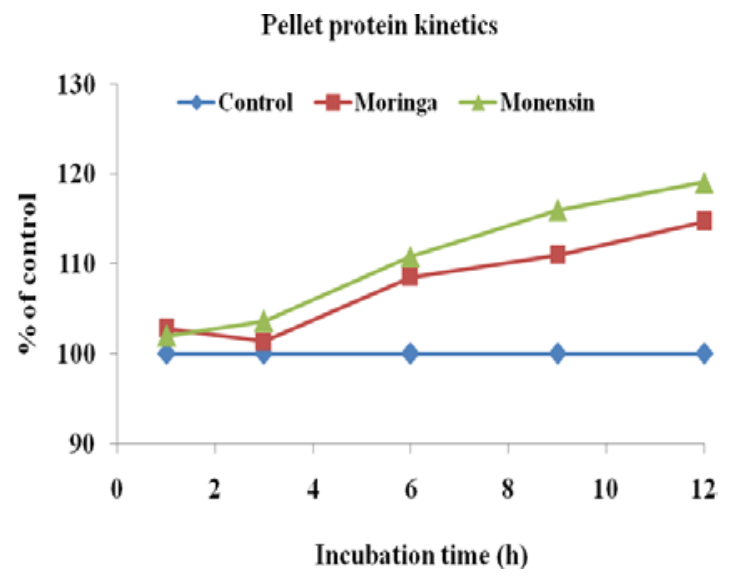

Figure 3. Cumulative pellet protein concentration kinetics of Moringa leaves

It is an accepted concept in ruminant nutrition to maximize substrate fixation into microbial cells to increase the efficiency of microbial protein synthesis and decrease in the protein degradability of feed protein in the rumen as they increase the supply of protein to the lower intestine for production purpose, resulting in higher milk, meat and wool and also reduce methane and $\mathrm{CO}_{2}$ production and nitrogen excretion to the environment, thereby reducing emission of environmental pollution (Beever 1993; Leng 1993; Van Soest 1994). Peptide and amino acid accumulation would be expected to be beneficial, firstly because rumen microorganisms would be able to assimilate preformed amino acids, saving the energy required for their biosynthesis and secondly because some of these compounds may escape undegraded from the rumen and be utilized by the host (Wallace 
1994). The inhibition of amino acid degradation in the rumen is an obvious objective for manipulation. Even if the amino acids were not to pass undegraded from the rumen, if they were to be incorporated directly into microbial protein instead of being degraded to ammonia and then resynthesized, the energy cost of resynthesis would be saved. Therefore, amino acid breakdown may be nutritionally expensive not only because amino acids are lost, but also because of the high energetic costs of their breakdown. It can be predicted from the present findings that Moringa leaf may have similar properties to accumulate SP and PP in the rumen as of Monensin and there is a possibility to use this leaf extract as growth promoting agent like ionophore but need further investigation for confirmation and recommendation.

\section{Conclusion}

It can be concluded from the present findings that feeding Moringa leaves appear to be an alternative source of protein and are safe for ruminant animals. The Moringa leaves have been shown to alter favorably ruminal protein fermentation characteristics thus spare protein by a decreased breakdown/deamination of protein/ amino acids that functions as of Monensin need further investigation for confirmation.

\section{References}

Amin MR (2011). The miracle multipurpose tree Moringa oleifera have the potentials to modulate rumen fermentation characteristics and conceivably capable to increase protein supply to the ruminants. BAU Research Progress, Bangladesh Agricultural University, Mymensingh, Bangladesh.

Barry TN, McNabb WC (1999). The implications of condensed tannins on the nutritive value of temperate forages fed to ruminants. British J ournal of Nutrition, 81: 263-272.

Beever DE (1993). Ruminant animal production from forages-present position and future opportunities, In: Baker MJ (edn), Grassland for our World. SIR Publishing, P. 158.

Gupta K, Barat GK, Wagle DS, Chawla HKL (1989). Nutrient contents and anti- nutritional factors in conventional and nonconventional leafy vegetables. Food Chemistry, 31: 105-116.

Hofmann EM, Muetzel S, Becker K (2003). Effects of Moringa oleifera seed extract on rumen fermentation in vitro. Archives of Animal Nutrition, 57: 65-81.

Kabir AKMA, Alam MR, Amin MR (2004). Effect of tannins on organic matter digestibility and metabolizable energy content in three leguminous leaves. Progressive Agriculture, 15: 53-59.

Leng RA (1993). Quantitative ruminant nutritionA green science, Australian Journal of Agricultural Research, 44: 363-380.

Lowry OH, Rosenbrough NJ, Farr A. Randall RJ (1951). Protein measurement with the Folin phenol reagent. Journal of Biological Chemistry, 193: 265-275.

Makkar HPS (2000). Quantification of tannins in tree foliage. A laboratory manual for the FAO/IAEA coordinated research project on "Use of nuclear and related techniques to develop simple tannin assays for predicting and improving the safety and efficiency of feeding ruminants on tanniniferous tree foliage. FAO/IAEA working document, IAEA, Vienna, Austria.

Makkar HPS, Becker K (1996). A bioassay for polyphenols (Tannins). In: Vercauteren J, Cheze C, Dumon MC, Weber JF (eds), Proceedings of the $18^{\text {th }}$ International Conference on Polyphenols, Bordeaux (France). Polyphenols Communications, 1: 197-198.

Makkar HPS, Bliimmel M, Becker K (1995). Formation of complexes between polyvinyl pyrrolidones or polyethylene glycols and tannins, and their implication in gas production and true digestibility in in vitro techniques. British J ournal of Nutrition, 73: 897-913.

Mangan JL (1988). Nutritional effects of tannins in animal feeds. Nutrition Research Reviews, 1: 209-231.

Mehansho H, Butler LG, Carlson DM (1987). Dietary tannins and salivary proline rich proteins: Interaction, induction and defence mechanisms. Annual Review of Nutrition, 7: 423-440.

Menke KH, Raab L, Salewski A, Steingass H, Fritz 
D, Schneider, W (1979). The estimation of the digestibility and metabolizable energy content of ruminant feedingstuffs from the gas production when they are incubated with rumen liquor in vitro. The Journal of Agricultural Science, 93: 217-222.

Menke KH, Steingass H (1988). Estimation of the energetic feed value obtained from chemical analysis and in vitro gas production using rumen fluid. Animal research and development, 28: 7-55.

Michelet-Doreau B, Ould-Bah MY (1992). In vitro and in sacco methods for the estimation of dietary nitrogen degradability in the rumen: a review. Animal Feed Science and Technology, 40: 57-86.

Newbold CJ, Wallace RJ, Watt ND, Richardson AJ (1988). Effect of the novel ionophore tetronasin $(\mathrm{ICl}$ 139603) on ruminal microorganisms. Applied Environmental Microbiology, 54: 544-547.

Palmer B, Jones RJ (2000). The effect of PEG addition in vitro on dry matter and nitrogen digestibility of Calliandra calothyrsus and Leucaena leucocephala leaf. Animal Feed Science and Technology, 85: 259-268.

Russell JB, Onodera R, Hino T (1991). Ruminal protein fermentation: New perspectives on previous contradictions. In: Physiological Aspects of Digestion and Metabolism in
Ruminants - Tsuda S, Sasaki Y, Kawashima R, Academic Press, San Diego, CA, P. 681697.

Santos FAP, Santos JEP, Theurer CB, Hubber JT (1998). Effects of rumen degradable protein on dairy cow performance: A 12year literature review. Journal of Dairy Science, 81: 3182-3213.

Van Soest PJ (1994). Nutritional ecology of ruminants, $2^{\text {nd }}$ edn. Cornell University Press, P. 476.

Waghorn GC, Stafford KJ (1993). Gas production and nitrogen digestion by rumen microbs from deer and sheep. New Zealand Journal of Agricultural Research 36: 493-497.

Wallace RJ (1994). Amino Acid and Protein Synthesis, Turnover, and Breakdown by Ruminal Microorganisms. In: Principles of Protein Nutrition of Ruminants. Edited by $\mathrm{J}$. M. Asplund, Ph. D., CRC Press Ink. London, Tokyo. P. 71-111.

Yang CM, Russell JB (1993). The effect of monensin supplementation on ruminal ammonia accumulation in vivo and the numbers of amino acid-fermenting bacteria. Journal of Animal Science, 71: 3470-3476. 